\title{
Determining the minimum ripening time of artisanal Minas cheese, a traditional Brazilian cheese
}

\author{
José M. Martins ${ }^{1}$, Éder Galinari ${ }^{2}$, Natan J. Pimentel-Filho ${ }^{2}$, José I. Ribeiro $\mathrm{Jr}^{3}$, \\ Mauro M. Furtado ${ }^{4}$, Célia L.L.F. Ferreira ${ }^{4}$ \\ ${ }^{1}$ Instituto Federal de Educação, Ciência e Tecnologia, Rio Pomba, MG, Brazil. \\ ${ }^{2}$ Departamento de Microbiologia, Universidade Federal de Viçosa, Viçosa, MG, Brazil. \\ ${ }^{3}$ Departamento de Estatística, Universidade Federal de Viçosa, Viçosa, MG, Brazil. \\ ${ }^{4}$ Departamento de Tecnologia de Alimentos, Universidade Federal de Viçosa, Viçosa, MG, Brazil.
}

Submitted: September 17, 2013; Approved: June 6, 2014.

\begin{abstract}
Physical, physicochemical, and microbiological changes were monitored in 256 samples of artisanal Minas cheese from eight producers from Serro region (Minas Gerais, Brazil) for 64 days of ripening to determine the minimum ripening time for the cheese to reach the safe microbiological limits established by Brazilian legislation. The cheeses were produced between dry season (April-September) and rainy season (October-March); 128 cheeses were ripened at room temperature $\left(25 \pm 4^{\circ} \mathrm{C}\right)$, and 128 were ripened under refrigeration $\left(8 \pm 1{ }^{\circ} \mathrm{C}\right)$, as a control. No Listeria monocytogenes was found, but one cheese under refrigeration had Salmonella at first 15 days of ripening. However, after 22 days, the pathogen was not detected. Seventeen days was the minimum ripening time at room temperature to reduce at safe limits of total coliforms $>1000 \mathrm{cfu}^{-\mathrm{g}^{-1}}$ ), Escherichia coli and Staphylococcus aureus $\left(>100\right.$ cfu. $\left.\mathrm{g}^{-1}\right)$ in both periods of manufacture. Otherwise under refrigeration, as expected, the minimum ripening time was longer, 33 days in the dry season and 63 days in the rainy season. To sum up, we suggest that the ripening of artisanal Minas cheese be done at room temperature, since this condition shortens the time needed to reach the microbiological quality that falls within the safety parameters required by Brazilian law, and at the same time maintain the appearance and flavor characteristics of this traditional cheese.
\end{abstract}

Key words: ripening, artisanal Minas cheese, Serro, pathogen, lactic acid bacteria.

\section{Introduction}

Artisanal cheeses are produced in many countries and have specific properties depending on the region where they are made. In Brazil, the State of Minas Gerais is known as the major cheeses producer, and the Serro region is among the main production regions of the artisanal Minas cheeses. The artisanal Minas cheese is made from raw cow's milk, mainly involving family labor, which, in most cases, does not have sufficient resources to adapt their production facilities to improve the product quality. The marketing of artisanal food products in a safe and sustainable way is one of the main challenges faced by family farmers in Brazil; it still receives little attention from government agencies responsible for its development. In an attempt to improve the quality of artisanal Minas cheese, the government has created laws that establish the physicochemical and microbiological parameters to which these cheeses must adhere (Minas Gerais, 2002, 2008). However, to be commercialized throughout the country, the cheese must meet the standards required by federal law (Brasil, 2000) that stipulate a minimum ripening time of 60 days for cheeses made from raw milk to ensure safety since the process of ripening can contribute significantly to the reduction of pathogens in such products.

Ripening is a complex phenomenon that involves physical, physicochemical, and microbiological changes 
that occur in cheese under the influence of environmental factors and enzymatic and organic acids produced, mostly by natural milk microbiota (Dolci et al., 2010; Sihufe et al., 2010). This microbiota - composed mostly by lactic acid bacteria (LAB) - are more complex than industrial starter cultures added to pasteurized milk during cheese making and play a strong role in lipolysis and proteolysis, resulting in compounds responsible for flavor and texture characteristics. Most LAB release substances that control undesirable microorganisms counts in cheese (Cabezas et al., 2005; González et al., 2007).

Since these cheeses are microbiologically safe, new perspectives may be established in order to characterize them in each producing region, with the adoption of quantitative descriptive analysis and especially certification of origin, which can guarantee recognition for making a genuine traditional cheese to the cheese maker. This adds value to the product and protects it from the clandestinity. Considering the excessively long ripening time established by Brazilian law and the intention of characterizing artisanal Minas cheese, this research aimed to study the physical, physicochemical, and microbiological changes that occur in this cheese during the ripening, suggesting a minimum ripening time at room temperature that ensures microbiological safety and at the same time maintains the traditional sensory characteristics. These cheeses are traditionally ripened at room temperature, but due to legislation requirements that establish packaging and refrigeration during ripening, we included refrigeration as a control treatment. This is the first study that characterizes a Brazilian artisanal cheese and provides relevant information to support cheese makers in obtaining protected geographical indication status.

\section{Materials and Methods}

\section{Sampling and conditions of cheese ripening}

We randomly selected eight producers who make artisanal Minas cheese (and are affiliated with the Farmers Cooperative of Serro) at different levels of adequacy to legislation requirements for good agricultural practices (Minas Gerais, 2002).

Aliquots of $100 \mathrm{~mL}$ of water, endogenous culture (EC), and milk used to manufacture cheeses were collected from each farm. After two days of production, at the end of salting, the cheeses were collected from the farms of origin. Water samples, EC, milk, and cheeses with two days of production were microbiologically analyzed as described at topic 2.4. A total of 256 cheese samples were collected in two seasons, dry season (April-September) and rainy season (October-March).

The average temperature and relative humidity (RH) storage of cheeses during the ripening were: i) dry season: ripening at room temperature $\left(23 \pm 2{ }^{\circ} \mathrm{C}\right.$ and $\left.62 \% \mathrm{RH}\right)$ and ripening in a cold chamber $\left(8 \pm 1^{\circ} \mathrm{C}\right.$ and $\left.75 \% \mathrm{RH}\right)$; and ii) rainy season: ripening at room temperature $\left(27 \pm 2{ }^{\circ} \mathrm{C}\right.$ and $68 \% \mathrm{RH})$ and ripening in cold chamber at $\left(8 \pm 1{ }^{\circ} \mathrm{C}\right.$ and $77 \% \mathrm{RH})$. The cheeses ripened at room temperature were stored without packaging in a metal cabinet, with mesh on either side for ventilation and shelves lined with aluminum foil. The cheeses were washed with potable water and turned every two days. The samples ripened under refrigeration were vacuum-packed and stored on shelves in a cold chamber. Physical, physicochemical, and microbiological analysis were performed on the cheeses at 8, 15, 22, 29, 36, 50 , and 64 days of ripening.

\section{Physical analysis}

The weight of the cheeses was determined using a digital scale (Filizola, Model BP15, Brazil). Height and diameter were measured with a ruler.

\section{Physicochemical analysis}

The cheeses were analyzed for acidity (AOAC, 1990), fat (IDF, 1969), moisture (IDF, 1982) and chlorides (IDF, 1988). The $\mathrm{pH}$ was measured using a portable digital pH meter (Tecnal, Model 102) using a specific electrode for cheese. Fat in dry matter (FDM) was determined indirectly as follows: $\% \mathrm{FDM}=(\% \mathrm{~F} / \% \mathrm{DM}) \times 100$, in which $\% \mathrm{~F}$ is the fat content of the sample and $\% \mathrm{DM}$ is the content of total solids in the sample (AOAC, 1995). The water activity $\left(\mathrm{A}_{\mathrm{w}}\right)$ was determined using an Aqualab device (Decagon Model CX2T). Total nitrogen (TN), pH 4.6 soluble nitrogen $(\mathrm{pH} 4.6 \mathrm{SN})$, and soluble nitrogen in $12 \%(\mathrm{v} / \mathrm{v})$ trichloracetic acid (TCA-SN) were determined by the Kjeldahl method (IDF, 1993). The total protein (TP) content was determined indirectly by multiplying the percentage of TN by a factor of 6.38, indicated for protein derived from milk (IDF, 1993). Ripening extension index (REI; Eq. (1)) and ripening depth index (RDI; Eq. (2)) were calculated:

$$
\begin{aligned}
& \mathrm{REI}=(\mathrm{pH} 4.6 \mathrm{SN} / \mathrm{TN}) \times 100 \\
& \mathrm{RDI}=(\mathrm{TCA}-\mathrm{SN} / \mathrm{TN}) \times 100
\end{aligned}
$$

\section{Microbiological analysis}

For microbiological analysis, $25 \mathrm{~g}$ of each cheese were sampled by removing a slice from the center to the periphery of the cheese, in different areas, using a sterile cheese trier. Each sample was homogenized with $225 \mathrm{~mL}$ of $0.12 \%(\mathrm{w} / \mathrm{v})$ sterile phosphate buffer solution in a Stomacher 400 Bagmixer $^{(B)}$ (Model VW, France) for 2 min at low speed. Serial decimal dilutions were performed before plating in depth. The total mesophilic aerobe count was determined in samples of milk according to the American Public Heath Association (2001). Total coliform bacteria and Escherichia coli were enumerated in samples of water, milk, EC, and cheese, and Staphylococcus aureus were enumerated in milk samples, EC, and cheese using specific Petrifilm $^{\circledR}$ plates (3M, Minnesota, USA). Salmonella spp. and Listeria monocytogenes were evaluated in the cheeses 
beginning at two days of ripening using Reveal ${ }^{\circledR}$ kits (Neogen, Miami, USA).

\section{Staphylococcal enterotoxins analysis}

We evaluated the presence of staphylococcal enterotoxins in samples of artisanal Minas cheese, in the dry and rainy seasons, using the qualitative immunoenzimatic test VIDAS ${ }^{\circledR}$ Staph Enterotoxin (BioMérieux, Marcy-l'Étoile, France) that allows simultaneous detection of seven different enterotoxins (SEA, SEB, SEC1, SEC2, SEC3, SED, SEE).

\section{Statistical analysis}

The research was performed on scheme of subdivided parcels, in which the parcels consist of ripening conditions (room temperature and refrigeration) in a randomized block design with eight replicates (cheese makers). The sub-parcels consisted of periods of manufacture (dry and rainy seasons), and the sub-sub-parcels consisted of ripening time $(2,8,15,22,29,36,50$, and 64 days). Analysis of the cheeses two days after manufacture was carried out only for the determination of microbial counts, without the interference of the ripening period.

Data were subjected to variance analysis (ANOVA) analysis to determine the main effects and interactions of second and third orders among the three factors studied (period of manufacture, ripening condition, and ripening time). Depending on the significance of the interactions, we performed an F-test to compare means of two ripening conditions and the two periods of manufacture at the $5 \%$ significance level. We conducted regression analysis on the ripening time for each combination of the ripening conditions and period of manufacture, the coefficients of which were subjected to a Student's t-test up to the 5\% significance level. All statistical analysis were performed in software SAEG 9.1 (UFV, Viçosa, Minas Gerais, Brazil).

\section{Results and Discussion}

\section{Physical characteristics of cheeses}

The ripening at room temperature reduced $(p<0.05)$ the average weight, height, and diameter in both periods of manufacture, while the refrigeration caused no effect $(p>0.05)$ (Figure 1). The explanation for this phenomenon is the loss of moisture from the cheeses. Moreover, the refrigerated cheeses retained their moisture content due to the presence of a plastic film that hinders moisture exchange with the environment. The diameter was the parameter that showed the greatest homogeneity among the samples, possibly due to use of moulds with a similar diameter among the cheese makers. Because artisanal Minas cheese is not part of the certification systems that establish criteria for standardization, starting with their own sizing, these results demonstrate the heterogeneity among producers.

\section{Physicochemical characteristics of cheeses}

The lactic acid concentration was not affected $(p>0.05)$ by temperature and ripening time. However, the period of manufacture affected $(\mathrm{p}<0.05)$ almost all parameters, except for $A_{w}$, sodium chloride, moisture, and weight. Fat in dry matter was affected $(p<0.05)$ by the condition of ripening and the period of manufacture. Cheeses ripened at room temperature showed higher FDM means $(\mathrm{p}<0.05)$ than the cheeses ripened under refrigeration $\left(53.29^{\mathrm{a}}\right.$ and $49.90^{\mathrm{b}}$, respectively). When the cheeses were manufactured in the dry season, they also had higher FDM means $(\mathrm{p}<0.05)$ than those made during rainy season $\left(53.45^{\mathrm{a}}\right.$ and $49.74^{\mathrm{b}}$, respectively). The cheeses can be classified based on the content of FDM, in accordance with the standards established by federal legislation (Brasil, 1996). Thus, the cheeses in this study, regardless of ripening time or temperature, were classified as fat (45 to $59.9 \%$ FDM).

Interactions $(p<0.05)$ were observed between the factors temperature and period of manufacture for TCA-SN and RDI. In both periods of manufacture, the RDI of cheeses was higher $(p<0.05)$ at room temperature, and in this same condition of ripening, RDI values were higher $(\mathrm{p}<0.05)$ in cheeses during the rainy season (Table 1). These data indicate that higher temperatures accelerate the process of cheese ripening, especially those made from raw milk, due to the greater presence of aminopeptidases and cell lysis, with the release of endo- and exopeptidases (Gorostiza et al., 2004; Grappin and Beuvier, 1998).

The temperature and ripening time factors affected $(p<0.05)$ various physicochemical parameters, except for FDM, lactic acid, and REI. In general, all cheeses that were ripened at room temperature showed lower $(\mathrm{p}<0.05)$ mean $A_{w}$ and moisture over much of the entire ripening time, while sodium chloride, TN, TP, and $\mathrm{pH} 4.6 \mathrm{SN}$ had higher $(\mathrm{p}<0.05)$ means in the same conditions. These results can be explained by the water loss of cheeses due to elevated temperatures $\left(23-27^{\circ} \mathrm{C}\right)$ and low RH $(62-68 \%)$.

An interaction $(p<0.05)$ between the ripening time and period of manufacture occurred for $\mathrm{A}_{\mathrm{w}}$, sodium chloride, $\mathrm{pH}$, lactic acid, $\mathrm{pH}$ 4.6 SN, REI, TCA-SN and RDI. The average sodium chloride means were higher $(\mathrm{p}<0.05)$ during the dry season, but only at 29 days and 36 days of ripening. Dry salting used by cheese makers in Serro does not allow for the standardization of the salt content in

Table 1 - Averages of RDI artisanal Minas cheese of the Serro region, according to the period of manufacture and condition of ripening.

\begin{tabular}{lcc}
\hline Period of manufacture & \multicolumn{2}{c}{ Ripening temperature } \\
\cline { 2 - 3 } & Room & Refrigeration \\
\hline Rainy season & $10.05 \mathrm{a} \mathrm{A}$ & $7.20 \mathrm{a} \mathrm{B}$ \\
Dry season & $8.50 \mathrm{~b} \mathrm{~A}$ & $6.97 \mathrm{a} \mathrm{B}$ \\
\hline
\end{tabular}

Means followed by same lowercase letter in the columns, and uppercase letter in the lines, do not differ based on the results of an F-test $(p>0.05)$. 
cheese. The rainy season had higher $(p<0.05)$ mean $A_{w}$ than the dry season only at 36 days of ripening. This result correlates with the sodium chloride measurements, in which it was inversely proportional to $\mathrm{A}_{\mathrm{w}}$. The $\mathrm{pH}$ means were higher $(p<0.05)$ during the rainy season throughout the entire ripening time, whereas the lactic acid means were higher $(p<0.05)$ during the dry season, beginning with the third week of ripening. In production areas of artisanal Minas cheese, it is common to use a greater amount of EC during the dry season, offsetting the adverse effects of lower temperatures on the fermentation process, which explains the differences between the two periods of manufacture for $\mathrm{pH}$ and lactic acid.

The averages of $\mathrm{pH} 4.6 \mathrm{SN}$ over the entire ripening period and REI from 29 days on were higher $(\mathrm{p}<0.05)$ during ripening in the rainy season, possibly due to increased temperature in this period, which favors the action of coagulating enzymes in the breakdown of casein, forming large peptides from intermediate size. The RDI had higher means $(\mathrm{p}<0.05)$ during the rainy season, but only after 50 days of ripening.

The interaction among ripening time, ripening condition, and period of manufacture occurred $(p<0.05)$ only for fat and TCA-SN. Cheeses ripened at room temperature showed higher $(p<0.05)$ mean of fat contents than cheeses refrigerated during the entire ripening time in both periods of manufacture. The loss of moisture from the cheese was facilitated by environmental conditions (higher temperatures and low RH) that increased the total solids, and consequently the fat content, during ripening. Furthermore, the cheeses made in the dry season had higher $(p<0.05)$ mean of fat contents than those made during the rainy season, but only after 22 days for cheeses ripened at room temperature, and after 50 days for refrigerated cheese. The fat content of milk varies depending on the season, the type of animal feed used, genetic factors such as animal size, weight, and production, animal age, and the period of lactation (Bell et al., 2006; Shingfield et al., 2006; Stanton et al., 1997). Higher TCA-SN $(\mathrm{p}<0.05)$ means were found in cheeses ripened at room temperature, in both periods of manufacture throughout virtually the entire ripening time. However, after 22 days, the rainy season had the highest $(p<0.05)$ average of TCA-SN when the cheeses were ripened at room temperature. Under refrigeration, time did not affect mean TCA-SN $(p<0.05)$ in both periods of manufacture.

We observed gradual increases $(\mathrm{p}<0.05)$ in fat (Figure 1), TN, and $\mathrm{pH}$ (Figure 2) in both periods of manufacture when the cheeses were ripened at room temperature, which was not verified in the refrigerated cheeses $(\mathrm{p}<0.05)$, as occurred in other artisanal cheeses (Caridi et al., 2003a; Cichoski et al., 2002; Raphaelides et al., 2005). The increases $(p<0.05)$ in fat and TN of the ripened cheeses at room temperature are directly related to moisture loss of cheese during the ripening time, which contributes to the concentration of total solids, while in the refrigerated cheeses, these parameters remain practically unchanged. The increase $(\mathrm{p}<0.05)$ in $\mathrm{pH}$ during ripening at room temperature may be due to protein degradation from the activity of native milk protease (plasmin) and the protease present in the EC, with the formation of alkaline nitrogenous compounds.

Means of lactic acid concentrations (Figure 2) were not affected $(p<0.05)$ by ripening time in both periods of manufacture and in the two ripening conditions. In the presence of calcium, lactic acid can be converted to calcium lactate, maintaining its equilibrium (Chevanan et al., 2006).

Means of $\mathrm{pH}$ 4.6 SN (Figure 2) and TCA-SN (Figure 3 ) concentrations increased $(\mathrm{p}<0.05)$ throughout ripening in both periods of manufacture and ripening conditions, especially at room temperature. Higher temperatures favor primary proteolysis, represented by $\mathrm{pH} 4.6 \mathrm{SN}$, which is formed by the breakdown of proteins during cheese ripening, primarily involving the conversion of large casein peptides, mainly due to residual action of the coagulant with $\alpha$-S1, $\beta$-, and $\gamma$-caseins (Bertolino et al., 2011). The highest average of TCA-SN $(p<0.05)$ at room temperature can be explained by the presence of low molecular weight substances (amino acids, oligopeptides, amines, and others), also responsible for the sensory characteristics of cheeses, which accumulate during the ripening time due especially to the proteolytic action of microbial enzymes (Prieto et al., 2004).

Throughout ripening in both periods of manufacture, the moisture and $\mathrm{A}_{\mathrm{w}}$ (Figure 3 ) decreased $(\mathrm{p}<0.05)$ in cheeses stored at room temperature, while the sodium chloride content (Figure 3) increased $(\mathrm{p}<0.05)$. Moreover, none of these parameters changed $(\mathrm{p}<0.05)$ throughout the ripening time in refrigerated cheeses.

Federal law (Brasil, 1996) classifies cheeses by their moisture content, so the cheeses in this research that were ripened under refrigeration were classified as high moisture (46 to $54.9 \%$ ). In contrast, ripened cheeses at room temperature were classified as medium moisture (36 to $45.9 \%$ ) when they were at 8 to 17 days of ripening and low moisture $(<36 \%)$ after 18 days of ripening. During ripening, higher temperatures accelerate decrease in the moisture content of cheeses and, consequently, reduce $\mathrm{A}_{\mathrm{w}}$ with increased total solids, such as sodium chloride (Cabezas et al., 2005; Öner et al., 2006; Prieto et al., 2004). In general, sodium chloride, $\mathrm{A}_{\mathrm{w}}$, and redox potential, as well as other physicochemical factors such as lactic acid and $\mathrm{pH}$, can directly influence the microbiota present in cheese, contributing to their microbiological safety.

\section{Microbiological analysis of water, endogenous culture, and milk}

Of water samples, $56.25 \%$ were found to be above the standards required by legislation for coliforms (absence in $100 \mathrm{~mL}$ ) and were up $31.25 \%$ for E. coli (data not shown). The coliform counts were slightly higher during the rainy 
DRY SEASON


Ripening time (days)
RAINY SEASON
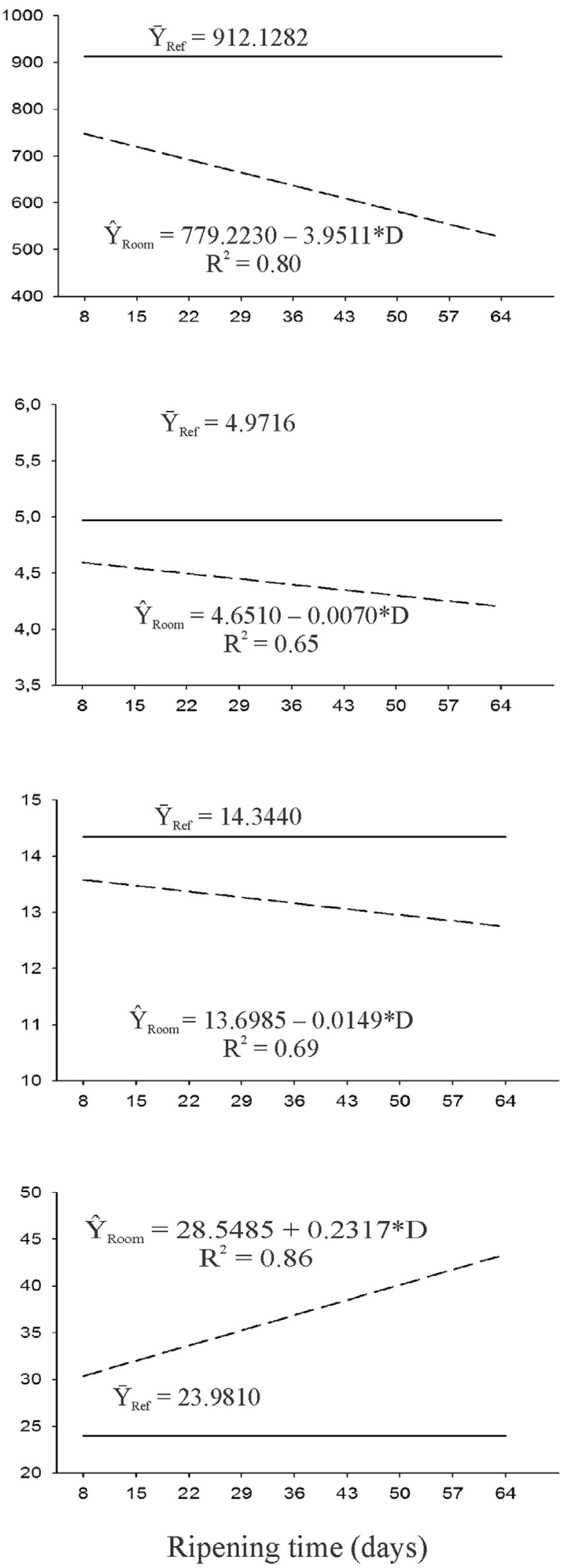

Figure 1 - Estimates of weight, height, diameter, and fat content in samples of artisanal Minas cheese from the region of Serro, as a function of the ripening time in days (D). Room - ripening at room temperature, Ref - ripening under refrigeration. *Significant by Student's t-test $(p<0.05)$. 
DRY SEASON
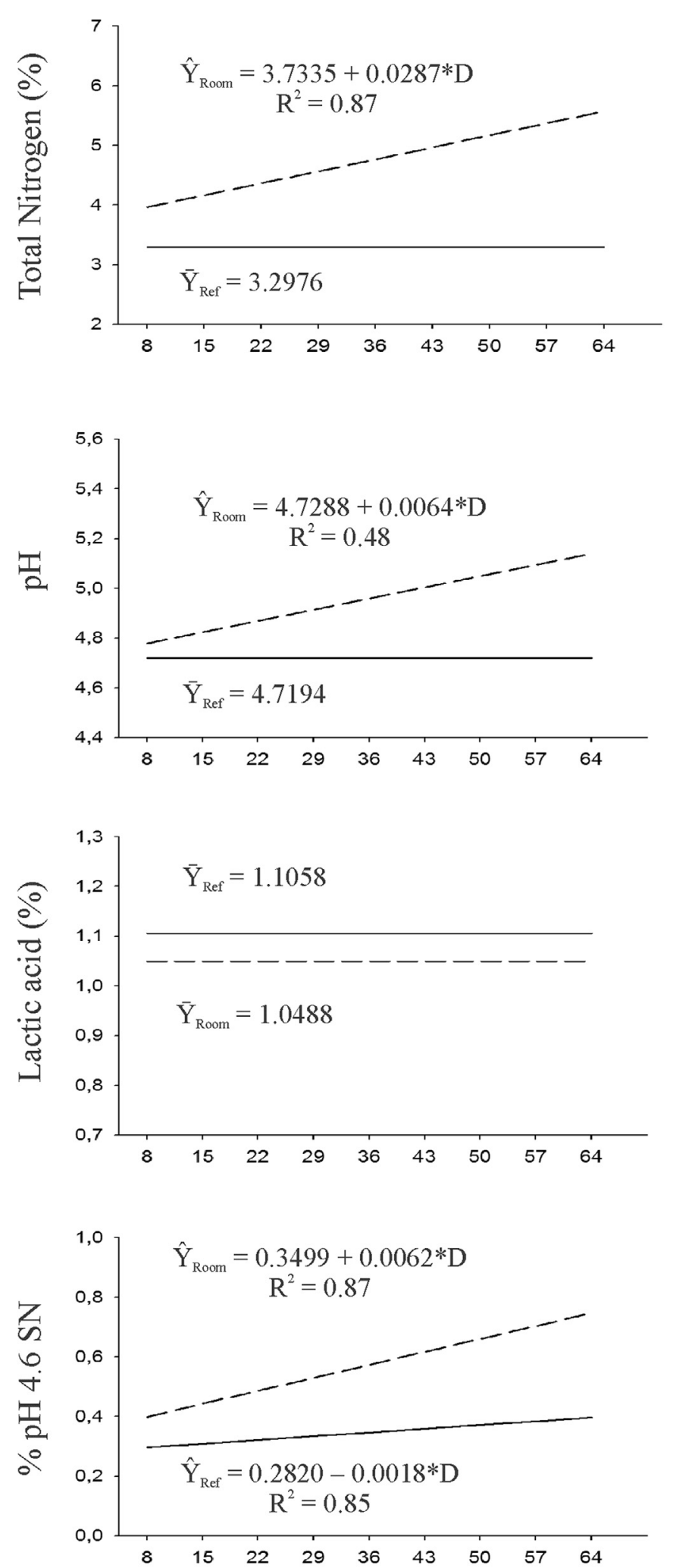

Ripening time (days)
RAINY SEASON
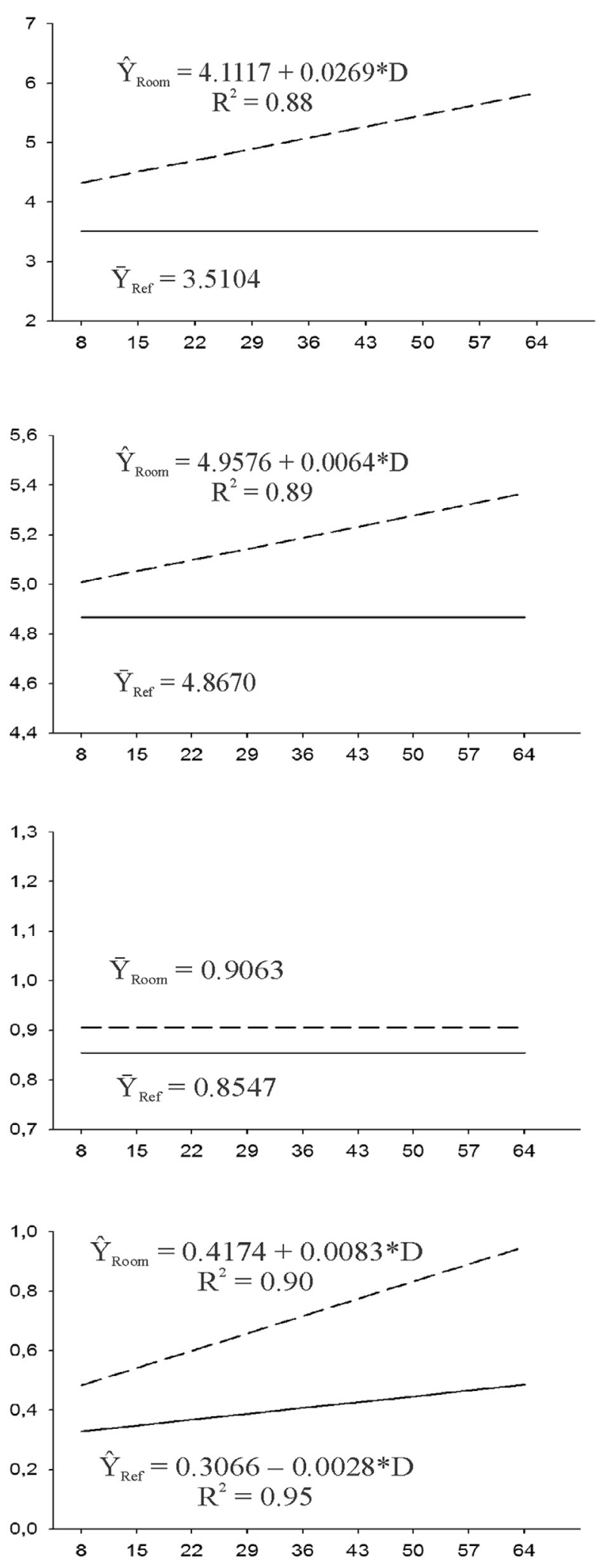

Ripening time (days)

Figure 2 - Estimates of total nitrogen, $\mathrm{pH}$, lactic acid, and pH 4.6 SN in samples of artisanal Minas cheese from the region of Serro, as a function of the ripening time in days (D). Room - ripening at room temperature, Ref - ripening under refrigeration. *Significant by Student's t-test $(\mathrm{p}<0.05)$. 
DRY SEASON
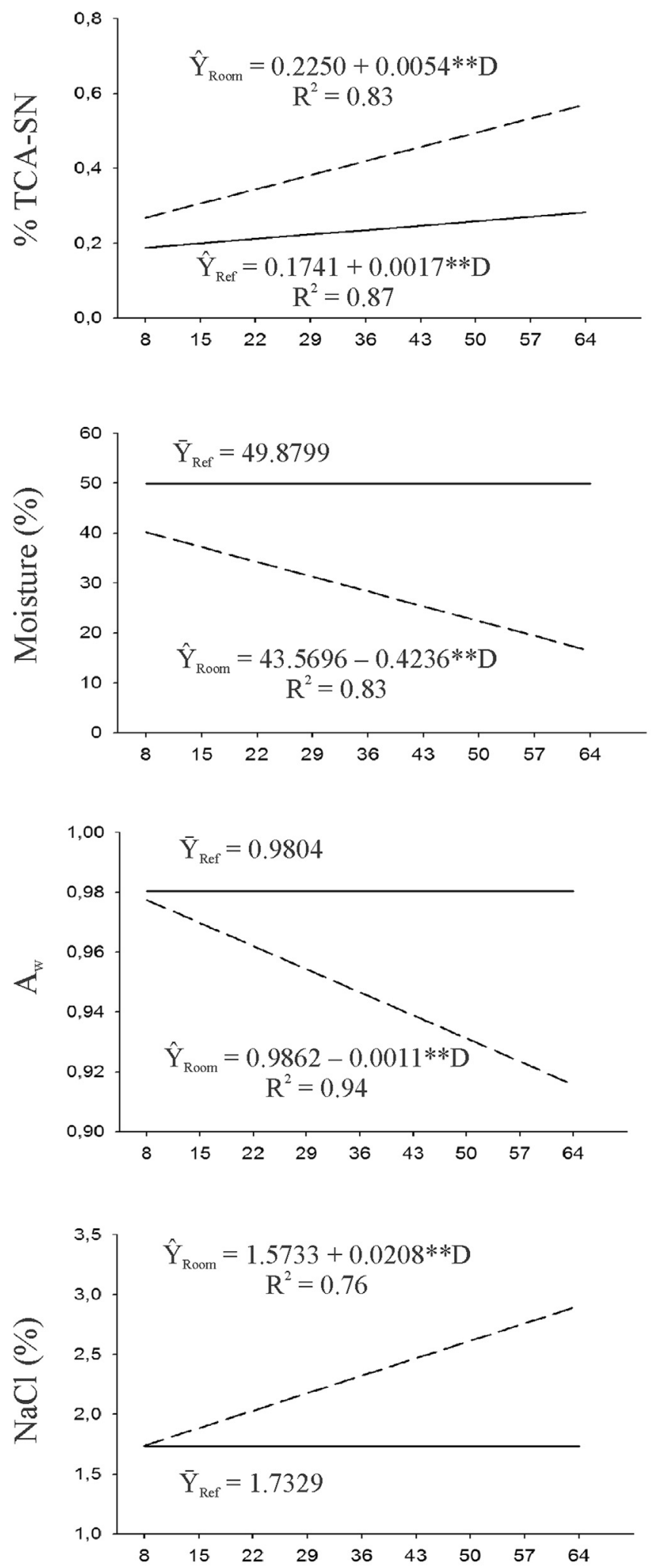

Ripening time (days)
RAINY SEASON
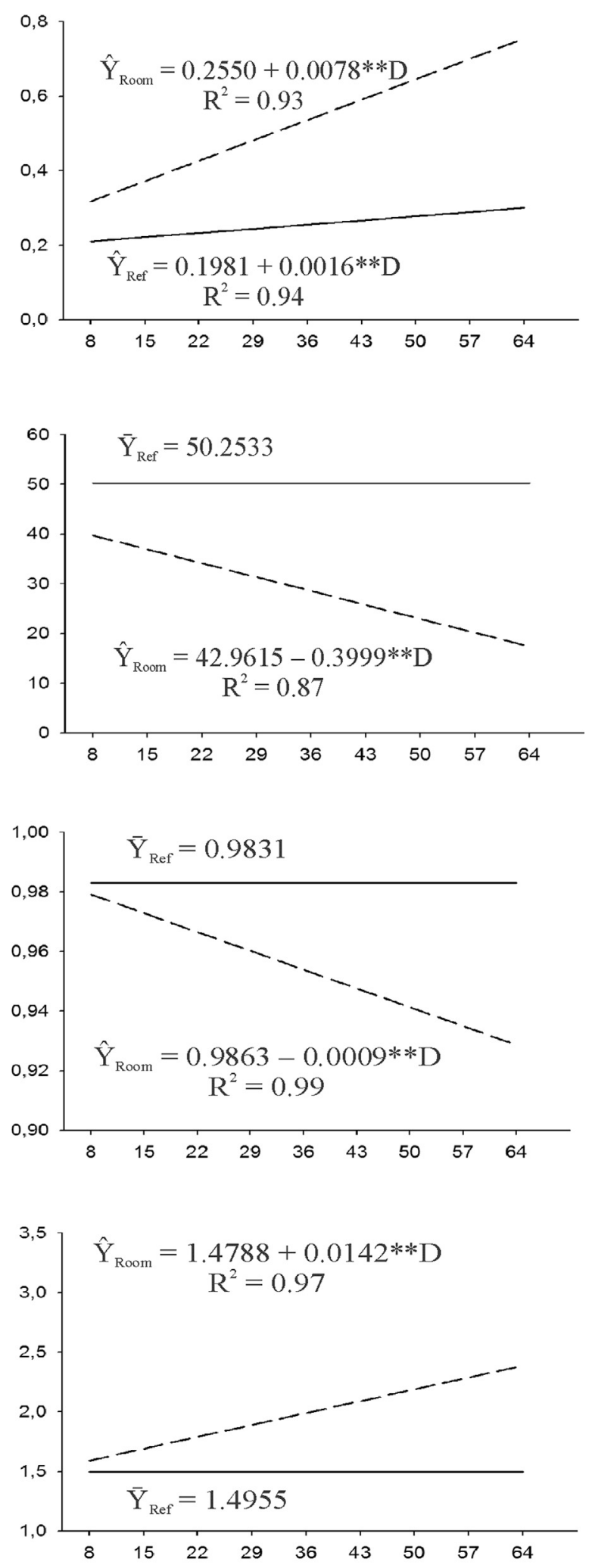

Ripening time (days)

Figure 3 - Estimates of TCA-SN, moisture, $\mathrm{A}_{\mathrm{w}}$, and $\mathrm{NaCl}$ in samples of artisanal Minas cheese from the region of Serro, as a function of the ripening time in days (D). Room - ripening at room temperature, Ref - ripening under refrigeration. *Significant by Student's t-test $(\mathrm{p}<0.05)$. 
Table 2 - Mean $\left(\log\right.$ cfu. $\left.\mathrm{mL}^{-1}\right)$ microbiological counts of endogenous culture and milk used in the manufacture of artisanal Minas cheese from the region of Serro.

\begin{tabular}{|c|c|c|c|c|c|}
\hline Period of manufacture & Sample & Aerobic mesophiles & Coliforms & E. coli & S. aureus \\
\hline \multirow[t]{2}{*}{ Dry season } & Endogenous culture & - & 3.08 & 2.18 & 2.46 \\
\hline & Milk & 5.79 & 4.04 & 1.50 & 4.43 \\
\hline \multirow[t]{2}{*}{ Rainy season } & Endogenous culture & - & 3.36 & 2.23 & 2.41 \\
\hline & Milk & 5.93 & 4.91 & 1.78 & 3.45 \\
\hline Lesgilation & Milk & $<5.00$ & - & $<2.00$ & $<2.00$ \\
\hline
\end{tabular}

- not required by legislation.

season. The presence of $E$. coli indicates recent fecal contamination, and thus, that water cannot be used. The adoption of an appropriate treatment to ensure the physicochemical and microbiological safety of water, such as the use of efficient filters and chlorination systems, is very important in artisanal Minas cheese production, since it is essential for cleaning facilities and equipment. Table 2 presents the mean microbial counts of milk and EC used in the manufacture of artisanal Minas cheese from the region of Serro. The EC, which is collected at the end of syneresis of the cheeses, presented in the two periods of manufacture high counts of coliforms, E. coli, and S. aureus, although legislation does not establish any standard for this raw material. The difference in the counts of these contaminants in the dry and rainy season was minimal $\left(<10 \mathrm{cfu} \cdot \mathrm{mL}^{-1}\right)$. The lack of standardization in the salting of the cheese directly affects the salt content in EC (Pimentel Filho et al., 2005) and consequently its microbiota. S. aureus can be found in EC, since they are halophilic microorganisms and multiply in food at salt concentrations of up to 15\% (Le Loir et al., 2003). However, even with the presence of contaminating microorganisms, the EC had a predominance of lactic acid bacteria (Galinari et al., 2011), which inhibits the growth of pathogenic microorganisms (Mafu et al., 2011; Zmantar et al., 2010).

The counts of mesophilic aerobes, coliforms, and $E$. coli in milk were slightly higher during the rainy season, but the opposite occurred for $S$. aureus, which was higher during the dry season (Table 2). In both periods of manufacture, mesophilic aerobes and $S$. aureus counts were above the limits of legislation $\left(>5 \log\right.$ cfu. $\mathrm{mL}^{-1}$ and $>2 \mathrm{Log}$ cfu. $\mathrm{mL}^{-1}$, respectively), indicating deficiencies in good manufacturing practices. Thus, the contamination of the water samples, milk, and EC are related to inadequate sanitary conditions found in the production units, since the health of the herd, affected by the possible presence of mastitis, must be carefully controlled until the final stages of production of cheese (when EC is collected) to improve the quality of the final product.

\section{Microbiological analysis of the cheeses}

For coliforms, E. coli, and S. aureus, the conditions of cheese ripening were determined to promote the reduction of these contaminants. From 29 days of ripening at room temperature, the counts of these microorganisms were lower than $10 \mathrm{cfu}^{-1} \mathrm{~g}^{-1}$ for all samples (Figure 4). The opposite was found in cheeses ripened under refrigeration, which had higher microorganism counts, with results verified through 64 days. Therefore, given the large difference between the two ripening conditions, the ANOVA for the contaminants group considered the simple effect and the interactions of only two factors, ripening time and cheese manufacture. For cheeses ripened at room temperature, the ANOVA indicated a simple effect $(\mathrm{p}<0.05)$ of the ripening time on all contaminants. For coliforms, there was an interaction $(p<0.05)$ between the periods of ripening and cheese production, with the highest $(p<0.05)$ average occurring in the rainy season in the early ripening, which did not occur again after the $8^{\text {th }}$ day. In the rainy season, the first six days of ripening (between the $2^{\text {nd }}$ and $8^{\text {th }}$ day) were sufficient to reduce the initial counts of coliforms more than $2 \mathrm{log}$. Furthermore, ANOVA of the cheese samples ripened under refrigeration indicated the simple effect of $(p<0.05)$ the period of manufacture on coliforms and $S$. aureus and ripening time for all groups of contaminants. It was verified that coliforms and $S$. aureus were higher $(\mathrm{p}<0.05)$ during the rainy season when compared with counts in the dry season. We confirmed that the sanitary conditions of production units should be more closely observed in the rainy season, during which bacterial growth is favored because of the high humidity.

The ripening time caused a negative linear effect on the count of coliforms, E. coli, and S. aureus, especially the cheeses ripened at room temperature, which had lower counts for cheeses refrigerated throughout virtually whole ripening time (Figure 4). The initial count of contaminants was high at the beginning of ripening, mainly in the rainy season, when the temperature and RH were higher. According to Masoud and Jakobsen (2005), the increase in temperature implies directly in higher microbial growth in cheeses, whether endogenous, added, or contaminant. Some factors contributed to the high initial count, among them the low microbiological quality of milk and EC and possible contamination caused by handlers and the intrinsic characteristics of cheeses, such as the high moisture content and substrate availability, favoring microbial multiplica- 
ROOM TEMPERATURE

\section{REFRIGERATION}

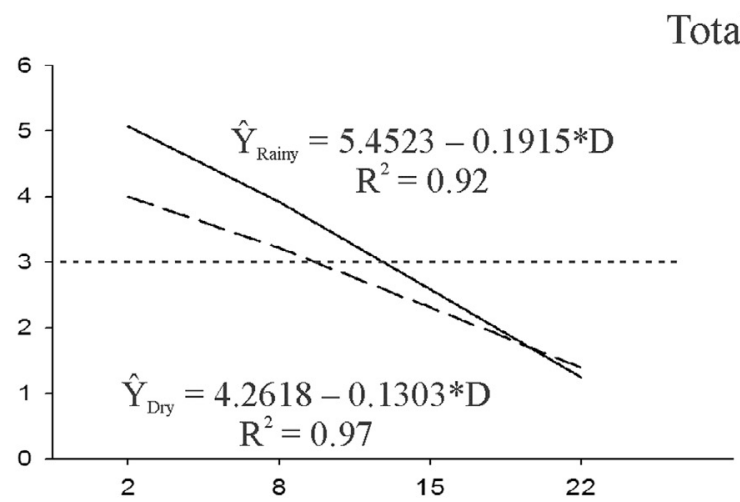

Total coliforms

Escherichia coli
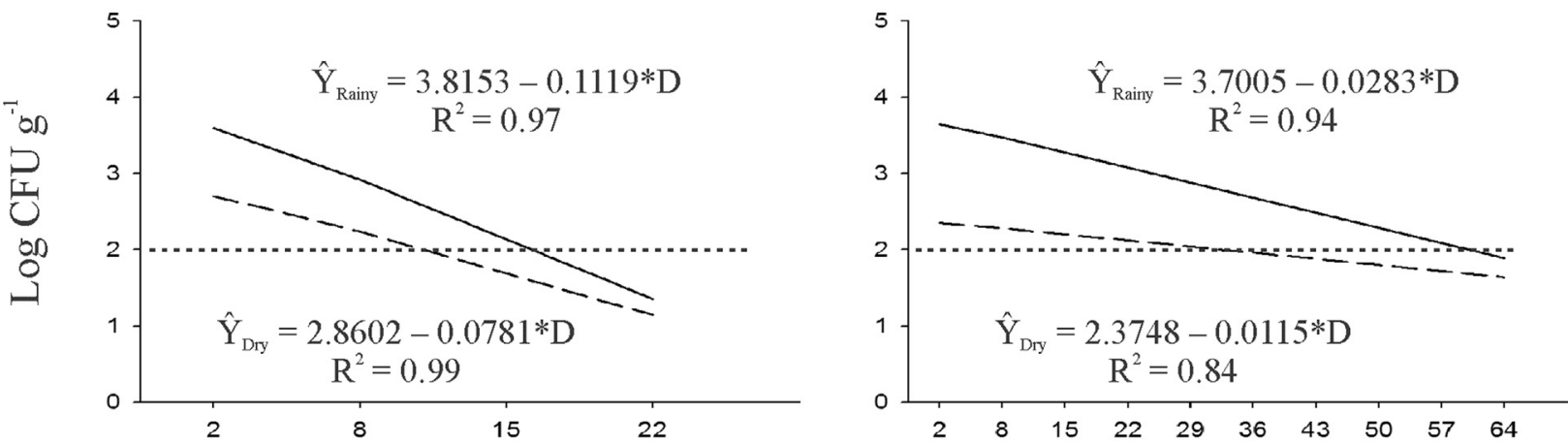

\section{Staphylococcus aureus}

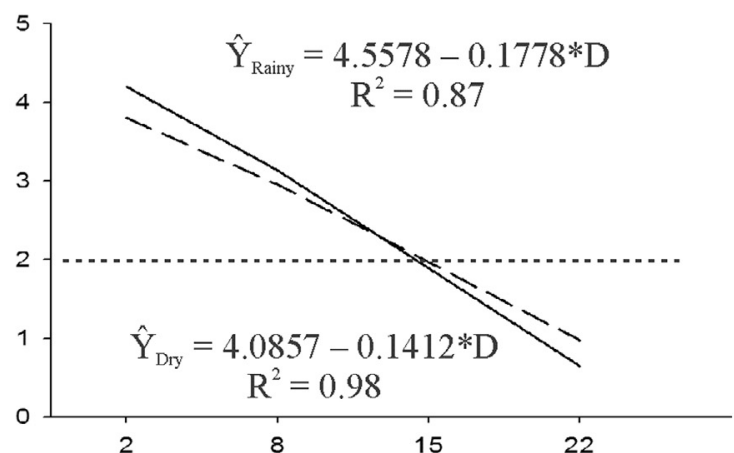

Ripening time (days)

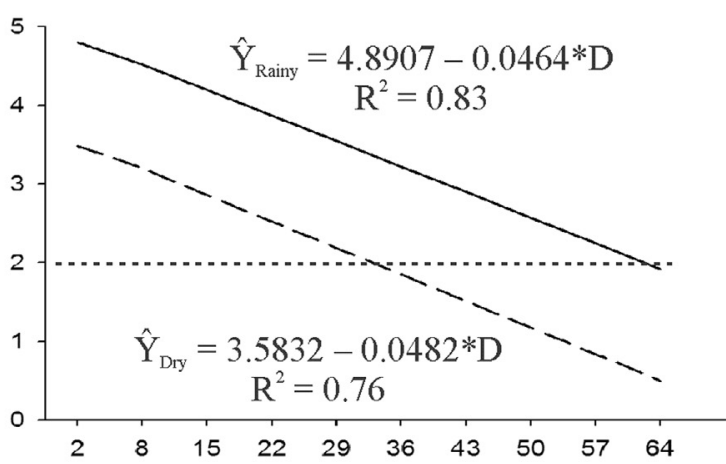

Ripening time (days)

Figure 4 - Counted estimates of total coliforms, E. coli and S. aureus in samples of artisanal Minas cheese from the region of Serro, ripened at room temperature and under refrigeration as a function of the ripening period (Rainy - filled line; Dry - dashed line). *Significant by Student's t-test ( $\mathrm{p}<0.05$ ). Dotted lines indicate the microbiological limits required by legislation of Minas Gerais after ripening.

tion. Since milk is not treated to remove contaminant microorganisms, proper hygiene practices should be put in place to reduce its initial count. An EC collected from contaminated whey will cause recontamination throughout the production process, since it is used in cheese manufacturing on the subsequent days.
In the course of ripening, the initial count of all microbial groups was gradually reduced $(\mathrm{p}<0.05)$ at a higher speed for cheeses ripened at room temperature. We also observed that the cheeses manufactured in the rainy season showed a severe reduction in counts within each condition of ripening. Even under refrigeration, microbial counts also 
decreased. However, the higher temperatures accelerate the ripening (Cabezas et al., 2005; Moatsou et al., 2004; Öner et al., 2006; Psoni et al., 2003). The ripening at room temperature caused a decrease in moisture content, and therefore, increasing the concentration of sodium chloride and reducing the $A_{w}$ in cheeses would significantly reduce contaminants. According to Beresford et al. (2001), beyond these factors, the low redox potential in cheeses favors the reduction of undesirable microorganisms. The conditions for inhibition developed during ripening occurs primarily by competition between the secondary microbiota and $\mathrm{LAB}$, which can predominate in the cheese by lactic acid production, reduced sugar content and redox potential and by producing antimicrobial compounds (Caridi et al., 2003b; Manolopoulou et al., 2003). By presenting a linear tendency for reduction of the microbiological count during ripening, it is suggested that this process would be favored if used milk with good microbiological quality to produce cheeses.

The results of this study make it clear that the cheeses made in the dry season, even those that present a smaller daily rate of microbial reduction during ripening than in the rainy season, quickly achieve the legislative standards (Minas Gerais, 2002, 2008). The cheeses ripened at room temperature showed microbiological counts within these standards for all the contaminants from 17 days of ripening. On the other hand, cheeses ripened under refrigeration achieved such standards at 33 days in the dry season and 63 days in the rainy season. No samples of cheese showed the presence of Listeria monocytogenes. However, samples of one producer, ripened under refrigeration and manufactured in the rainy season, had Salmonella spp. in the first two weeks (at 8 and 15 days ripening). However, after 22 days, even under refrigeration, Salmonella was not detected, probably due to the accumulation of lactic acid in the cheese and low $\mathrm{pH}$ values found in this sample $(<4.7)$. Several studies have demonstrated the antimicrobial activity of LAB against pathogens such as Listeria monocytogenes, S. aureus, E. coli, and Salmonella spp. (Caridi et al., 2003a; González et al., 2007; Macedo et al., 2004; Rodríguez et al., 2005). Higher temperatures can be an ally in cheese ripening by promoting the metabolism of $\mathrm{LAB}$ and the accumulation of metabolites responsible for the inhibition and elimination of contaminants. Therefore, the ripening of artisanal Minas cheese under refrigeration allows the placement of contaminated products on the market, representing risks to the consumer.

\section{Analysis of staphylococcal enterotoxin}

Although the initial counts of $S$. aureus in cheeses were above those established by present legislation, enterotoxins were not detected in any sample. This results indicates the possible presence in the cheese of some mechanism inhibiting the expression of genes related to toxin production. Further studies in this area must be done for conclusive statements, including the effects of the conditions (room temperature and refrigeration) and the ripening time on the pre-formed toxin.

\section{Conclusions}

The effects of ripening at room temperature on the physicochemical parameters of cheese directly influenced microbial behavior, causing a reduction in contaminant counts. Thus, at room temperature, 17 days was the minimum ripening time for the cheeses to reach the microbiological standards required by law. In turn, the cheeses ripened under refrigeration only reached such standards at 33 days for cheeses manufactured in the dry season and 63 days for those manufactured in the rainy season. Therefore, we suggest that the ripening of artisanal Minas cheese be done at room temperature, since this condition shortens the time needed to reach the microbiological quality that falls within the safety parameters required by legislation, and also maintain the appearance and flavor characteristics known by producers and consumers who appreciate the artisanal Minas cheese.

\section{Abbreviations}

ANOVA, variance analysis; EC, endogenous culture; FDM, fat in dry matter; LAB, lactic acid bacteria; $\mathrm{pH} 4.6$ $\mathrm{SN}, \mathrm{pH} 4.6$ soluble nitrogen; RDI, ripening depth index; REI, ripening extension index; $\mathrm{RH}$, relative humidity; TCA-SN, soluble nitrogen in $12 \%$ trichloracetic acid; TN, total nitrogen; TP, total protein; $A_{w}$, water activity.

\section{Acknowledgments}

This research was supported by CNPq. We would like to thank the cheese makers for supplying the samples.

\section{References}

AOAC (1990) Official Methods of Analysis of AOAC International. In: Official Method 920.124. Acidity of Cheese. 15th edition. Association of Official Analytical Chemists, Arlington.

AOAC (1995) Official Methods of Analysis of AOAC international. In: Official Method 926.08. Moisture in Cheese. 16th edition. Association of Official Analytical Chemists, Maryland.

American Public Health Association (2001) Compendium of Methods for the Microbiological Examination of Food. American Public Health Association, Washington, DC.

Bell JA, Griinari JM, Kennelly JJ (2006) Effect of safflower oil, flaxseed oil, monensin, and vitamin $\mathrm{E}$ on concentration of conjugated linoleic acid in bovine milk fat. J Dairy Sci 89:733-748.

Beresford TP, Fitzsimons NA, Brennan NL et al. (2001) Recent advances in cheese microbiology. Int Dairy J 11:259-274.

Bertolino M, Dolci P, Giordano M et al. (2011) Evolution of chemico-physical characteristics during manufacture and 
ripening of Castelmagno PDO cheese in wintertime. Food Chem 129:1001-1011.

Brazil. Ministério da Agricultura, Pecuária e Abastecimento. Secretaria de Defesa Agropecuária (2000) Departamento de Inspeção de Produtos de Origem Animal. Anexo I: Critérios de Funcionamento e de Controle da Produção de Queijarias, para Seu Relacionamento Junto ao Serviço de Inspeção Federal. Resolução n ${ }^{\circ}$ 07, de 28 de novembro de 2000.

Brazil. Diário Oficial da União. Portaria n ${ }^{\circ} 146$, de 7 de março de 1996 (1996) Aprova os regulamentos técnicos de identidade e qualidade dos produtos lácteos.

Cabezas L, Sánches I, Poveda JM et al. (2005) Comparison of microflora, chemical and sensory characteristics of artisanal Manchego cheeses from two dairies. Food Control 18:1117.

Caridi A, Micari P, Foti F et al. (2003a) Ripening and seasonal changes in microbiological and chemical parameters of the artisanal cheese Caprino d'Aspromonte producer from raw or thermized goat's milk. Food Microbiol 20:201-209.

Caridi A, Pietro M, Caparra P et al. (2003b) Ripening and seasonal changes microbial groups and in physico-chemical properties of the ewes' cheese Pecorino del Poro. Int Dairy J 13:191-200.

Chevanan N, Muthukumarappan K, Upreti P et al. (2006) Effect of calcium and phosphorus, residual lactose and salt-tomoisture ratio on textural properties of cheddar cheese during ripening. J Texture Stud 37:711-730.

Cichoski AJ, Valduga E, Valduga AT et al. (2002) Characterization of Prato cheese, a Brazilian semi-hard cow variety: evolution of physico-chemical parameters and mineral composition during ripening. Food Control 13:329-336.

Dolci P, Alessandria V, Rantsiou K et al. (2010) Microbial diversity, dynamics and activity throughout manufacturing and ripening of Castelmagno PDO cheese. Int J Food Microbiol 143:71-75.

Galinari E, Nóbrega JE, Andrade NJ et al. (2014) Microbiological aspects of the biofilm on wooden utensils used to make a Brazilian artisanal cheese. Braz J Microbiol 45:713-720.

González L, Sandoval H, Sacristán N et al. (2007) Identification of lactic acid bacteria isolated from Genestoso cheese throughout ripening and study of their antimicrobial activity. Food Control 18:716-722.

Gorostiza A, Cichoscki AJ, Valduga AT et al. (2004) Changes in soluble nitrogenous compounds, caseins and free amino acids during ripening of artisanal Prato cheese, a Brazilian semi-hard cows variety. Food Chem 85:407-414.

Grappin R, Beuvier E (1998) Possible implications of milk pasteurization on the manufacture and sensory quality of ripening cheese. Review Int Dairy J 7:751-761.

IDF (1969) Determination of the fat content of cheese and of processed cheese products. IDF standard 5A. International Dairy Federation, Brussels.

IDF (1982) Cheese and processed cheese - Total solid content. IDF standard 4A. International Dairy Federation, Brussels.

IDF (1988) Cheese and cheese products - Determination of chloride content. Pontetiometric titration method. IDF standard 88A. International Dairy Federation, Brussels.

IDF (1993) Milk determination of nitrogen content. IDF standard 20B. International Dairy Federation, Brussels.

Le Loir Y, Baron F, Gautier M (2003) Staphylococcus aureus and food poisoning. Genet Mol Res 2:63-76.
Macedo AC, Tavares TG, Malcata FX (2004) Influence of native lactic acid bacteria on the microbiological, biochemical and sensory profiles of Serra da Estrela cheese. Food Microbiol 21:233-240.

Mafu AA, Plumety C, Deschênes L et al. (2011) Adhesion of pathogenic bacteria to food contact surfaces: Influence of $\mathrm{pH}$ of culture. Int J Microbiol 2011:1-9.

Manolopoulou E, Sarantinopoulos P, Zoidou E et al. (2003) Evolution of microbial populations during traditional Feta cheese manufacture and ripening. Int $\mathrm{J}$ Food Microbiol 82:153-161.

Masoud W, Jakobsen M (2005) The combined effects of $\mathrm{pH}, \mathrm{NaCl}$ and temperature on growth of cheese ripening cultures of Debaryomyces hansenii and coryneform bacteria. Int Dairy J 15:69-77.

Minas Gerais. Lei 14.185, de 31 de janeiro de 2002. Dispõe sobre o processo de produção de queijo Minas artesanal. 2002. Available at: http://hera.almg.gov.br/cgi-bin/nph-brs?col=e\&d=NJMG \&p

$1 \& \mathrm{u}=\mathrm{http}: / /$ www.almg.gov.br/njmg/chama_pesquisa.asp\& SECT1 $=$ IMAGE \&SECT2 $=$ THESOFF $\&$ SECT $3=$ PLUROF F \&SECT6=HITIMG\&SECT7 $=$ LINKON $\& 1=20 \& \mathrm{r}=1 \& \mathrm{f}=\mathrm{G}$ $\&$ s1=DECRETO 42645 2002.NORM.\&SECT8=SOTEXTO. Accessed: Sep 17, 2013.

Minas Gerais. Decreto $n^{\circ} 44.864$, de $1^{\circ}$ de agosto de 2008. Altera o Regulamento da Lei ${ }^{\circ} 14.185$, de 31 de janeiro de 2002, que dispõe sobre o processo de produção de Queijo Minas Artesanal. Available at: http://imanet.ima.mg.gov.br/nova/gce/outros_documentos/ Decreto_44864.pdf. Accessed: Sep 17, 2013.

Moatsou G, Moschopoulou E, Georgala A et al. (2004) Effect of artisanal liquid rennet from kids and lambs abomasa on the characteristics of Feta cheese. Food Chem 88:517-525.

Öner Z, Karahan AG, Aloglu H (2006) Changes in the microbiological and chemical characteristics of an artisanal Turkish white cheese during ripening. LWT - Food Sci Technol 39:449-454.

Pimentel-Filho NJ, Martins JM, Cunha LR et al. (2005) Modulação de parâmetros microbiológicos e do $\mathrm{pH}$ pelo cloreto de sódio, no fermento endógeno utilizado na produção de queijo Minas artesanal do Alto Paranaíba. Revista do Instituto de Laticínios Cândido Tostes 345:295-298.

Prieto B, Franco I, Fresno JM et al. (2004) Effect of ripening time and type of rennet (farmhouse rennet from kid or commercial calf) on proteolysis during the ripening of León cow milk cheese. Food Chem 85:389-398.

Psoni L, Tzanetakis N, Litopoulo-Tzanetaki E (2003) Microbiological characteristics of Batzos, a traditional Greek cheese from raw goat's milk. Food Microbiol 20:575-582.

Raphaelides SN, Antoniou KD, Vasilliadou S, et al. (2005). Ripening effects on the rheological behaviour of Halloumi cheese. J Food Eng 76:321-326.

Rodríguez E, Calzada J, Arqués JL et al. (2005) Antimicrobial activity of pediocin-producing Lactococcus lactis on Listeria monocytogenes, Staphylococcus aureus and Escherichia coli O157:H7 in cheese. Int Dairy J 15:51-57.

Shingfield KJ, Reynolds CK, Hervas G et al. (2006) Examination of the persistency of milk fatty acid composition responses 
to fish oil and sunflower oil in the diet of dairy cows. J Dairy Sci 89:714-732.

Sihufe GA, Zorrilla SE, Perotti MC et al. (2010) Acceleration of cheese ripening at elevated temperature. An estimation of the optimal ripening time of a traditional Argentinean hard cheese. Food Chem 119:101-107.
Stanton C, Lawless F, Kjellmer G et al. (1997) Dietary influences on bovine milk cis-9, trans-11-conjugated linoleic acid content. J Food Sci 62:1083-1086.

Zmantar T, Kouidhi B, Miladi H et al. (2010) A microtiter plate assay for Staphylococcus aureus biofilm quantification at various $\mathrm{pH}$ levels and hydrogen peroxide supplementation. New Microbiol 33:137-145.

Associate Editor: Eduardo Cesar Tondo

All the content of the journal, except where otherwise noted, is licensed under a Creative Commons License CC BY-NC. 